\title{
CLUSTER ANALYSIS AS A TOOL OF EVALUATING CLUSTERS OF THE EU COUNTRIES BEFORE AND DURING GLOBAL FINANCIAL CRISIS FROM THE PERSPECTIVE OF THE LABOR MARKET
}

\author{
Tomáš PIVOŇKA \\ University of Economics, Prague \\ E-mail: Pivonkat@gmail.com \\ Tomáš LÖSTER \\ University of Economics, Prague \\ E-mail: tomas.loster@vse.cz \\ doi:10.13165/IE-13-7-4-01
}

\begin{abstract}
The aim of this paper is using cluster analysis to show changes in the clusters composition of $27 \mathrm{EU}$ countries during the current economic crisis. The authors use the characteristics of labor market as an input into cluster analysis. The situation on the labor market is one of the most discussed sections of countries' economies. The authors discuss the impact of the current economic crisis on the structure of labor market and the composition of the group of countries before (2008) and during (2012) the crisis. The authors use the method of cluster analysis to generate the group of countries. They have chosen the following indicators of labor market: unemployment of different year old groups, unemployment of gender groups and the rate of participation of these groups.
\end{abstract}

JEL classification: J21, C38.

Keywords: cluster analysis, unemployment, labor market, economic crisis.

Reikšminiai žodžiai: klasterinè analizè, nedarbas, darbo rinka, ekonominè krizè.

\section{Introduction}

In this paper, the authors use the method of cluster analysis to describe a group of countries by characteristics of labor market before and during the current economic crisis. Year 2008 represents the situation before the crisis and year 2012 describes the situation during the current crisis. The economic crisis affected the Member States of the European Union in different ways. There are countries with a high rate of unemployment in all groups of population, and the dynamics of increase in unemployment is very fast. This is especially obvious in countries in Southern Europe. However, there are also countries, which are doing well, e.g., Germany, the Netherlands and Nordic countries. 
The authors have chosen indicators of labor market, such as unemployment of different year old groups of citizens, unemployment of gender groups and the rate of participation of these groups of employers.

The aim of the paper is to describe the condition of labor market in the years 2008 and 2012 and then to discuss the impact of the economic crisis on labor market in the Member States of the European Union actual to the enlargement in 2007. Croatia, as a new member of the European Union since 2013, was not included into the analysis.

The paper consists of 5 main sections. In the first section, a short introduction of the labor market issues is presented. The following section describes the methods, which were used in the analysis and the next section describes chosen variables, which were used in the cluster analysis. The fourth section contains clusters of countries during the previously mentioned two years. The last section describes the situation in the European Union as a whole.

\section{Theoretical framework}

The labor market has been a frequently cited theme not only during the last years. Labor income, expressed as real wages multiplied by the time spent at work, contributes to household consumption. The labor income enters the household consumption constraint. The higher labor income, the higher consumption is.

During the last few years, the European Union has been facing a serious problem of unemployment. The unemployment can be divided into involuntary, frictional and voluntary (see Wickens, M., 2012):

- Involuntary unemployment: a group of people, who are willing to work at the going wage, but the job is not available. Involuntary unemployment is temporary and disappears in the period of booms. On the other hand, it increases in the period of recession.

- Frictional unemployment. This type of unemployment is rather permanent and is associated with the flow of workers between jobs.

- Voluntary unemployment. These unemployed people are not seeking to get a job, and thus, do not provide workforce. It can be said that they are out of the labor market.

The fluctuation in unemployment is narrowly associated with the output. The number of unemployed people increases in the days of recession. The European Union is facing the economic crisis, and thus, there is a higher unemployment rate. The current rate of unemployment is, thus, associated with the lack of vacancies, and thus, we talk about involuntary unemployment.

The structure of labor market can be described by many variables. The authors have chosen a rate of unemployment, a rate of participation, long term unemployment, the percentage of part-time job and the percentage of older employed people.

Individual countries in the European Union have been affected differently by the current crisis. Countries from the Southern Europe, such as Spain, Portugal and Greece, have been facing this problem the most. On the other hand, there are coun- 
tries, such as Germany, the Netherlands and Nordic countries, which are relatively in a good condition (see Masso, J.; Krillo, K., 2011; Sher, V., 2009 and Scarpetta, S.; Sonnet, A.; Manfredi, T., 2010).

The authors have used the method of cluster analysis to distinguish groups of countries before and during the economic crisis.

\section{Methodology}

The cluster analysis is a very popular multidimensional statistical method, which fundamental claim is classification (observation) of objects into groups (clusters). These objects are characterized by many variables (properties). The main requirement is as higher as possible a similarity of objects into one cluster in comparison with other different clusters. In other words, differences between objects in different clusters should be greater. For clustering, the authors have used various methods, as well as various rates of distances. The process of clustering can separate the object by different ways according to the used method and specifications. That is the reason why the results of analysis (creating groups of similar objects) should be validated by the success, which means comparing it with other methods. The process of validation of clustering procedure is called validity assessment and criteria of validating are called validity measures. Besides the choice of the most suitable method of clustering, it is quite common to specify the optimal number of clusters, among which objects will be divided. Unambiguous demarcation of the fact which of existing coefficients should be used in specific situation or under specific conditions has not been described in literature. The authors of coefficients have solved the problem of evaluating from a different perspective and using a different instrument. That is the reason why the comparison is not possible in many cases. But it can be said that evaluating results with usage of more than one coefficient together can be considered a right way (with reference on many authors of coefficient, see, for example, Halkidi, M.; Batistakis, Y.; Vazirgiannis, M., 2001). In some cases, it is necessary to evaluate the clustering results simultaneously with several factors.

In order to create clusters of objects (27 countries of the EU), the authors have used two-steps cluster analysis (see Řezanková, H.; Húsek, D.; Snášel, V., 2009). This method uses the Euclid's degree or likelihood rate. The method is consisted with two phases (see Řezanková, H.; Húsek, D.; Snášel, V., 2009). The objects have been clustered into smaller clusters in the first phases. Incremental clustering has been used here. The objects have been included into one of the existing clusters or the new cluster has been created. In this phase, it is referred to the so-called CF-tree, where each leaf contains final smaller clusters. Each input into the node (the base of the tree view) is determined by a CF- characteristic, which contains numbers of clusters. Each object of a particular input is characterized by the CF- characteristic and the object is placed most akin to the leaf node and consequently to the most similar input into this leaf. The CF-characteristic is recalculated after inclusion of objects into the input. In the second phase, all created smaller clusters are included into a predetermined number of clusters. The number of smaller clusters is much lower than the number of original objects and that is why hierarchical clustering, 
for example, can be used. The same rate of dissimilarity is used in both phases. SPSS system uses likelihood rate (see Řezanková, H.; Húsek, D.; Snášel, V., 2009).

\section{Coefficients for choice of numbers of clusters}

In order to set the optimal number of clusters, many procedures have been used. These procedures were based on knowledge of economic theory, suitable criteria and dendrogram. The process of clustering of countries into similar groups has been done using the statistical software IBM SPSS version 20, SYSTAT and STATISTICA.

Davies-Bouldin index DB is a rate, where values depend on the chosen method of clustering (see Davies, D. L.; Bouldin, D. W., 1979). In order to set the Davies-Bouldin index, it is needed to define the so-called dispersal of $h$-th cluster $S_{h}$. The dispersal can be expressed by the equation:

$$
S_{h}=\sqrt{\frac{\sum_{x_{i} \in C_{h}} D^{2}\left(\mathbf{x}_{i}, \overline{\mathbf{x}}_{h}\right)}{n_{h}},}
$$

where:

$n_{h}$ is a number of objects in $h$-th cluster; and

$D^{2}\left(\mathbf{x}_{i}, \mathbf{x}_{h}\right)$ is a distance of $i$-th object from centroid $h$-th cluster; and where holds

$S_{h} \geq 0$,

$S_{h}=0$, if the objects in the cluster are characterized by identical properties.

The distance between clusters is defined by its distances from its centroid measured by the Minkovski distance:

$$
\begin{aligned}
& D_{h h^{\prime}}=D\left(\overline{\mathbf{x}}_{h}, \overline{\mathbf{x}}_{h^{\prime}}\right), \\
& D_{h g}=D\left(\overline{\mathbf{x}}_{h}, \overline{\mathbf{x}}_{g}\right),
\end{aligned}
$$

where $\overline{\mathbf{x}}_{h}$ is the centroid of $h$-th cluster, $\overline{\mathbf{x}}_{h^{\prime}}$ is the centroid of $h^{\prime}$-th cluster, and $\overline{\mathbf{x}}_{g}$ is the centroid of $g$-th cluster.

The rate of similarity between $h$-th and $h^{\prime}$-th clusters is $A_{h h^{\prime}}$ and is based on dispersal of $h$-th and $h^{\prime}$-th cluster. Moreover, the following assumptions must hold (see Davies, D. L.; Bouldin, D. W., 1979):

$$
\begin{aligned}
& \text { 1. } A_{h h^{\prime}} \geq 0, \\
& \text { 2. } A_{h h^{\prime}}=A_{h^{\prime} h}, \\
& \text { 3. } A_{h h^{\prime}}=0 \text {, pokud } S_{h}=S_{h^{\prime}}, \\
& \text { 4. } A_{h h^{\prime}}>A_{h g}, \text { pokud } S_{h^{\prime}}=S_{g} \text { a } D_{h h^{\prime}}<D_{h g}, \\
& \text { 5. } A_{h h^{\prime}}>A_{h g}, \text { pokud } S_{h^{\prime}}>S_{g} \text { a } D_{h h^{\prime}}=D_{h g},
\end{aligned}
$$


where $S_{h}, S_{h^{\prime}}, S_{g}$ are dispersal $h$-th, $h^{\prime}$-th and $g$-th clusters, $D_{h h^{\prime}}, D_{h g}$ are distances between separate clusters defined by (4) and (5).

The rate of similarity $A_{h h^{\prime}}$ between $h$-th and $h^{\prime}$-th clusters can be expressed by the following formula if assumptions (6) to (10) hold

$$
A_{h h^{\prime}}=\frac{S_{h}+S_{h^{\prime}}}{D_{h h^{\prime}}} .
$$

The maximum rate of similarity between clusters $h$ a $h^{\prime}$ is $A_{h}$, that is,

$$
A_{h}=\max _{h, h \neq h^{\prime}} A_{h h^{\prime}} \text {. }
$$

The final Davies-Bouldin index is counted as an arithmetical $A_{h}$ by the following formula:

$$
I_{\mathrm{DB}}(k)=\frac{\sum_{h=1}^{k} A_{h}}{k} .
$$

The best composition of objects into different clusters is when the value of the Davies-Bouldin index is minimal. Low values of this index means that the clusters are well separable.

The optimal number of clusters is the value of $k^{*}$ with minimal value of the DaviesBouldin index in the framework of predetermined maximal number of clusters, that is,

$$
I_{\mathrm{DB}}\left(k^{*}\right)=\min _{2 \leq k \leq n-1} I_{\mathrm{DB}}(k) \text {. }
$$

CHF index (also, a pseudo F index) was designed by Calinski and Habarasz (see Calinski, T.; Harabasz, J., 1974). The CHF index is defined as the share of the average value of inter-cluster and the average value of intra-cluster variability, by the following formula:

$$
I_{\mathrm{CHF}}(k)=\frac{\frac{S S_{\mathrm{B}}}{k-1}}{\frac{S S_{\mathrm{W}}}{n-k}}=\frac{(n-k) \cdot S S_{\mathrm{B}}}{(k-1) \cdot S S_{\mathrm{W}}},
$$

where:

$S S_{\mathrm{B}}$ is a square sum between clusters (characteristics of the inter-cluster variability), $S S_{\mathrm{W}}$ is a square sum inside clusters (characteristics of the intra-cluster variability), $S S_{\mathrm{T}}$ is a total square sum (characteristics of total variability).

In the case of a separate square, we can say that:

$$
\begin{aligned}
& S S_{\mathrm{W}}=\sum_{h=1}^{k} \sum_{\mathbf{x}_{i} \in C_{h}} \sum_{t=1}^{m}\left(x_{i t}-\bar{x}_{h t}\right)^{2}, \\
& S S_{\mathrm{T}}=\sum_{i=1}^{n} \sum_{t=1}^{m}\left(x_{i t}-\bar{x}_{t}\right)^{2},
\end{aligned}
$$




$$
S S_{\mathrm{B}}=S S_{\mathrm{T}}-S S_{\mathrm{W}},
$$

where:

$k$ is a number of clusters,

$m$ is a number of variables, characterized by objects,

$n$ is a number of objects.

The CHF index is used for setting the optimal number of clusters $k^{*}$, that is,

$$
I_{\mathrm{CHF}}\left(k^{*}\right)=\max _{2 \leq k \leq n-1} I_{\mathrm{CHF}}(k) .
$$

RMSSTD index (the root-mean-square standard deviation index) measures homogeneity of new clusters and is based only on the intra-cluster variability (see Halkidi, M.; Batistakis, Y.; Vazirgiannis, M., 2001). It can be also used to set the optimal number of clusters.

The RMSSTD index is defined by the following formula:

$$
I_{\text {RMSSTD }}(k)=\sqrt{\frac{S S_{\mathrm{W}}}{m \cdot(n-k)}} .
$$

Lower values of the RMSSTD index characterize a better distribution into clusters. Higher values of this index indicate heterogeneous clusters. The optimal number of clusters is a breaking point in a graphical expression.

The first question in the analysis is to set the optimal number of clusters. The authors have used many criteria to make this decision and have finally set 4 clusters, based on evaluating coefficients, namely the CHF coefficient, the RMSSTD coefficient and the Davies-Bouldin coefficient. These coefficients were set in the SYSTAT system and their graphical representation is shown in the picture below (see Figure 1).

Figure 1. Evaluating criteria for setting the optimal number of clusters
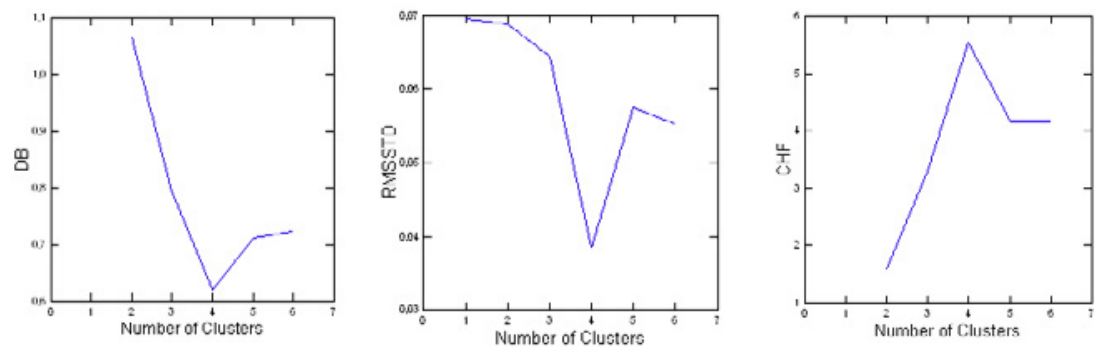

Source: Own calculation, SYSTAT system

A detailed calculation of the evaluating coefficients has been done by Gan, Ma and Wu (see Gan, G.; Ma, Ch.; Wu, J., 2007). 
The two-step cluster analysis has been used to create the group of countries. More detailed issues of cluster analysis can be found in a textbook devoted to cluster analysis by Řezanková, Húsek and Snášel (see Řezanková, H., Húsek, D., Snášel, V., 2009).

The calculation and the cluster evaluation have been done using the system IBM SPSS version 20. The model summary is presented in the picture below (see Figure 2).

Figure 2. Model summary

Model Summary

\begin{tabular}{|l|l|}
\hline Algorithm & TwoStep \\
\hline Inputs & 11 \\
\hline Clusters & 4 \\
\hline
\end{tabular}

Cluster Quality

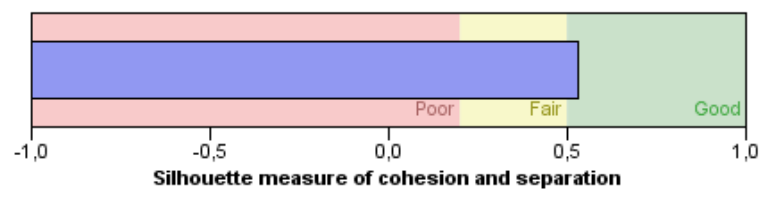

Source: Own calculation

\section{Chosen variables}

The labor market offers many variables, which could be chosen to analyze the structure of the labor market. In this analysis, the authors have divided employees by gender and by group of age. These characteristics are supplemented by the rate of parttime jobs on total jobs and by the share of 65 -plus year old employees on total number of employees.

The data needed for the analysis are available on the European statistics database EUROSTAT. The authors have used the chosen data from Labor Force Survey.

\section{The rate of unemployment}

The rate of unemployment is measured as a share of unemployed people in the economically active population (see Spěváček, V.; Vintrová, R.; Zamrazilová, E.; Ždárek, V.; Rojiček, M., 2010). The current economic crisis has negatively affected the labor market and the rate of unemployment has increased, especially in the Southern European countries.

If we distinguish employees by gender, we can say that the rate of unemployment of women is almost always higher than in the case of men in 2008. But there are some exceptions, e.g., Lithuania, Romania and the UK in 2008. The difference between these 
two groups has been diminishing during the last four years. The rates of unemployment of men and women were almost the same in 2012.

Very interesting characteristics were provided by the group of 20-24 year old population. These people can be considered as absolvents, and thus, as newcomers to the labor market. Although this group is more threatened by the risk of unemployment, there are higher differences between countries. More developed countries have the labor market more open to the newcomers, such as Germany, the Netherlands and Austria. On the other hand, there are countries with a higher rate of unemployment of young people, such as Spain, Greece, Portugal, Ireland and Italy. The impact of the current economic crisis was considerable when the rate of unemployment increased to $22 \%$ in 2012 from $12 \%$ in 2008 in EU-27. The worst situations were in Greece and Spain, where the rate is $53 \%$ and $49 \%$, respectively.

The topic of unemployment of different groups of employees has been discussed in many papers (see Azmat, G.; Güell, M.; Manning, A., 2006; Elder, S., 2010; Kieselbach, T., 2003).

\section{The rate of participation}

The rate of participation is measured as a share of active people in total population (see Spěváček, V.; Vintrová, R.; Zamrazilová, E.; Ždárek, V.; Rojíček, M., 2010). This characteristic describes how many people work or are able to work; thus, this indicator eliminates retired people, young people and others, who cannot work. It is obvious that the higher rate, the better.

The difference between men and women is substantial here. It can be said, regardless the year of observation, that the rate of participation of men is always higher in comparison with the rate of women. However, this is not surprising. A similar situation can be seen in the group of young people, where the rate of participation is smaller in comparison with the whole labor market (see Aaronson, S.; Fallick, B.; Figura, A.; Pingle, J., et al., 2006; Hotchkiss, J. L., 2009).

\section{Long term unemployment}

The unemployment, which lasts for longer than 12 months, is defined as a longterm unemployment (see Spěváček, V.; Vintrová, R.; Zamrazilová, E.; Ždárek, V.; Rojíček, M., 2010). This type of unemployment is very dangerous for the country's economy. People lose contact with practice and their employability is decreasing. These people can become dependent on aid from the state. The states, which are facing this kind of problem, are Greece, Spain, Portugal, Ireland and Slovakia. On the other side, Luxemburg and Sweden do not have such characteristic (see Chapman, B., 1993; Pavelka, T., 2012).

\section{Part-time jobs}

This characteristic can be considered as a proxy of flexibility of labor market. Countries with a higher share of part-time jobs in the total number of jobs have a more flexible labor market. Part-time jobs are arranged in a shorter period of time and are easily cancellable. The biggest portion of part-time jobs belongs to the 
Netherlands, where the share of part-time jobs reached almost 50\% in 2012. On the other hand, the lowest part-time/total job ratio is in Bulgaria and Slovakia, where the ratio was near to $2 \%$ in 2012. In addition, Kjeldstad and Nymoen investigated the part-time job and the differences between men and women in Norway (see Kjeldstad, R.; Nymoen, E. H., 2012).

\section{The ratio of 65-plus year old employed people in a total population employed}

This ratio bears the information about people in a retirement age, who decided to stay in work. The highest ratio was in Portugal, around 6\% in both years, and in Romania, the values being around $4 \%$.

\section{Cluster analysis}

The authors have used the method of cluster analysis to create groups of countries, which are similar in terms of structure of labor market. 4 groups of countries have been created with the usage of 11 variables mentioned above. The composition of clusters before the economic crisis, in 2008, and during the crisis, in 2012, is shown in the table below.

Table 1. Composition of clusters in 2008 and 2012

\begin{tabular}{|c|c|c|c|c|c|c|c|}
\hline \multicolumn{4}{|c|}{2008} & \multicolumn{4}{|c|}{2012} \\
\hline 1 & 2 & 3 & 4 & 1 & 2 & 3 & 4 \\
\hline Belgium & Malta & Lithuania & Greece & Estonia & Denmark & Belgium & Greece \\
\hline Bulgaria & \begin{tabular}{|l|} 
The \\
Netherlands
\end{tabular} & Luxembourg & Spain & Ireland & Germany & Bulgaria & Spain \\
\hline $\begin{array}{l}\text { Czech } \\
\text { Republic }\end{array}$ & Austria & Hungary & France & Cyprus & $\begin{array}{l}\text { The } \\
\text { Netherlands }\end{array}$ & $\begin{array}{l}\text { Czech } \\
\text { Republic }\end{array}$ & \\
\hline Denmark & Poland & & Italy & Latvia & Austria & France & \\
\hline Germany & Portugal & & Cyprus & Lithuania & Finland & Italy & \\
\hline Estonia & Romania & & Latvia & Portugal & Sweden & Luxembourg & \\
\hline Ireland & Slovenia & & & Slovakia & $\begin{array}{l}\text { United } \\
\text { Kingdom } \\
\end{array}$ & Hungary & \\
\hline & Slovakia & & & & & Malta & \\
\hline & Finland & & & & & Poland & \\
\hline & Sweden & & & & & Romania & \\
\hline & $\begin{array}{l}\text { United } \\
\text { Kingdom }\end{array}$ & & & & & Slovenia & \\
\hline
\end{tabular}

Source: Data from EUROSTAT database, own calculation

It is needed to mention here that the number of clusters does not mean the actual order. In other words, number 1 cannot be considered as a cluster of better countries 
than number 2 and so on. But it is possible to choose the best and the worst clusters, especially in 2012, when the differences were more considerable.

Cluster Number 3, which is composed of Lithuania, Luxemburg and Hungary, has the best values in almost all of the variables in 2008. But cluster Number 1 also seemed positive; therefore, even these countries belonging to this cluster were in a relatively good condition, too. Cluster Number 2, which contained the biggest amount of countries - 11, reached the worst values in comparison with other clusters. The output of the cluster analysis is presented in the table below, where the mean value of each variable is presented.

Table 2. Clusters description in 2008

\begin{tabular}{|c|c|c|c|c|c|c|c|c|}
\hline & \multicolumn{8}{|c|}{2008} \\
\hline & $\begin{array}{l}\text { Cluster } \\
\text { Number }\end{array}$ & Mean & $\begin{array}{c}\text { Cluster } \\
\text { Number }\end{array}$ & Mean & $\begin{array}{l}\text { Cluster } \\
\text { Number }\end{array}$ & Mean & $\begin{array}{c}\text { Cluster } \\
\text { Number }\end{array}$ & Mean \\
\hline $\begin{array}{l}\text { Rate of participation } \\
\text { of women }\end{array}$ & \multirow[t]{11}{*}{1} & 0.71 & \multirow[t]{11}{*}{2} & 0.59 & \multirow[t]{11}{*}{3} & 0.73 & \multirow[t]{11}{*}{4} & 0.59 \\
\hline $\begin{array}{l}\text { Unemployment rate } \\
\text { of women }\end{array}$ & & 0.06 & & 0.09 & & 0.04 & & 0.06 \\
\hline $\begin{array}{l}\text { Rate of participation } \\
\text { of men }\end{array}$ & & 0.80 & & 0.74 & & 0.84 & & 0.77 \\
\hline $\begin{array}{l}\text { Unemployment rate } \\
\text { of men }\end{array}$ & & 0.07 & & 0.07 & & 0.03 & & 0.04 \\
\hline $\begin{array}{l}\text { Rate of participation } \\
\text { of } 16-64 \text { year-olds }\end{array}$ & & 0.75 & & 0.67 & & 0.78 & & 0.68 \\
\hline $\begin{array}{l}\text { Unemployment rate } \\
\text { of } 15-64 \text { year-olds }\end{array}$ & & 0.07 & & 0.08 & & 0.03 & & 0.05 \\
\hline $\begin{array}{l}\text { Unemployment rate } \\
\text { of } 20-24 \text { year-olds }\end{array}$ & & 0.11 & & 0.18 & & 0.06 & & 0.10 \\
\hline $\begin{array}{l}\text { Rate of participation } \\
\text { of } 20-24 \text { year-olds }\end{array}$ & & 0.73 & & 0.55 & & 0.79 & & 0.61 \\
\hline Part-time jobs & & 0.17 & & 0.10 & & 0.31 & & 0.08 \\
\hline $\begin{array}{l}\text { Older employers/ } \\
\text { total population } \\
\text { employed }\end{array}$ & & 0.03 & & 0.02 & & 0.02 & & 0.02 \\
\hline $\begin{array}{l}\text { Long term } \\
\text { unemployment }\end{array}$ & & 0.00 & & 0.01 & & 0.00 & & 0.01 \\
\hline
\end{tabular}

Source: Own calculations

The situation in 2012 was a little different. Here, cluster Number 2 can be chosen as the best group of countries, based on the values of chosen variables. This group is composed of countries from Northern Europe, such as Denmark, Finland and Sweden, together with Western Europe countries, such as Germany, the Netherlands, Austria and the UK. These countries can be considered as the most stable countries in terms of the structure of labor market. 
The economic crisis has separated two countries from the rest of Europe - Greece and Spain, which are facing the biggest problems in these days. These countries had the highest rate of unemployment in all chosen groups. The overall rate of unemployment was over $20 \%$, and the unemployment rate of young people reached $50 \%$.

The description of the clusters in 2012 is presented in the table below.

Table 3. Clusters description in 2012

\begin{tabular}{|c|c|c|c|c|c|c|c|c|}
\hline & \multicolumn{8}{|c|}{2012} \\
\hline & \begin{tabular}{|c|} 
Cluster \\
Number \\
\end{tabular} & Mean & $\begin{array}{l}\text { Cluster } \\
\text { Number }\end{array}$ & Mean & \begin{tabular}{|c|} 
Cluster \\
Number \\
\end{tabular} & Mean & \begin{tabular}{|c|} 
Cluster \\
Number \\
\end{tabular} & Mean \\
\hline $\begin{array}{l}\text { Rate of participation } \\
\text { of women }\end{array}$ & \multirow[t]{11}{*}{1} & 0.68 & \multirow[t]{11}{*}{2} & 0.73 & \multirow[t]{11}{*}{3} & 0.60 & \multirow[t]{11}{*}{4} & 0.63 \\
\hline $\begin{array}{l}\text { Unemployment rate } \\
\text { of women }\end{array}$ & & 0.13 & & 0.06 & & 0.09 & & 0.27 \\
\hline $\begin{array}{l}\text { Rate of participation } \\
\text { of men }\end{array}$ & & 0.77 & & 0.82 & & 0.74 & & 0.79 \\
\hline $\begin{array}{l}\text { Unemployment rate } \\
\text { of men }\end{array}$ & & 0.15 & & 0.07 & & 0.09 & & 0.23 \\
\hline $\begin{array}{l}\text { Rate of participation } \\
\text { of } 16-64 \text { year-olds }\end{array}$ & & 0.72 & & 0.78 & & 0.67 & & 0.71 \\
\hline $\begin{array}{l}\text { Unemployment rate } \\
\text { of } 15-64 \text { year-olds }\end{array}$ & & 0.14 & & 0.07 & & 0.09 & & 0.25 \\
\hline $\begin{array}{l}\text { Unemployment rate } \\
\text { of } 20-24 \text { year-olds }\end{array}$ & & 0.27 & & 0.12 & & 0.21 & & 0.51 \\
\hline $\begin{array}{l}\text { Rate of participation } \\
\text { of } 20-24 \text { year-olds }\end{array}$ & & 0.60 & & 0.73 & & 0.52 & & 0.56 \\
\hline Part-time jobs & & 0.11 & & 0.27 & & 0.12 & & 0.11 \\
\hline $\begin{array}{l}\text { Older employers/ } \\
\text { total population } \\
\text { employed }\end{array}$ & & 0.03 & & 0.02 & & 0.02 & & 0.01 \\
\hline $\begin{array}{l}\text { Long term } \\
\text { unemployment }\end{array}$ & & 0.03 & & 0.01 & & 0.01 & & 0.04 \\
\hline
\end{tabular}

Source: Own calculations

\section{The impact of the current economic crisis on the European Union labor market}

The authors have discussed the impact of the current economic crisis on labor market of 27 European Union countries in the table presented below this text. Here, data comparison in 2008, as it was a year before the crisis, and data comparison in 2012, which represents the year of crisis, are shown. The column titled "Mean" is the average value of variables in 27 European Union countries in a chosen year. 
The rate of unemployment in all chosen groups increased. The biggest deterioration of the situation on labor market is associated with younger population, where the unemployment rate grew by 10 percent on average. But even the overall unemployment recorded increased by 4 percent. Not only the mean value, but even the minimum and the maximum values increased. Especially, the maximum values increased considerably. These extremely high rates of unemployment were in Spain and Greece. That is the reason why these two countries created a separate cluster in the cluster analysis.

The rate of participation was more or less unchanged. It is possible to see that the participation of women increased by 4 percent, but there was also deterioration in the group of young people. The share of active people in the total population in this group of people has decreased during the last 4 years by 4 percent on average.

The part time/total job ratio has increased by 2 percent in 27 European Union countries during the last four years. The increase was seen in almost every European Union 27 country, except Poland and Sweden. The highest growth of this indicator was recorded in Ireland and Latvia, where the share increased by 5 percent and 3 percent, respectively. But there are still big differences between 27 European Union countries of, as a standard deviation is relatively high, which reaches around $10 \%$.

The long term unemployment stayed almost unchanged, near to the value of $2 \%$ on average.

Table 4. The impact of the crisis on labor market

\begin{tabular}{|l|c|c|c|c|c|c|c|c|c|}
\hline & \multirow{2}{*}{$\mathbf{N}$} & \multicolumn{3}{|c|}{2008} & \multicolumn{4}{|c|}{2012} \\
\cline { 4 - 10 } & & Min & Max & Mean & $\begin{array}{c}\text { Std. } \\
\text { Dev. }\end{array}$ & Min & Max & Mean & $\begin{array}{c}\text { Std. } \\
\text { Dev. }\end{array}$ \\
\hline Rate of participation of women & 27 & 0.40 & 0.77 & 0.64 & 0.08 & 0.48 & 0.78 & 0.66 & 0.07 \\
\hline Unemployment rate of women & 27 & 0.03 & 0.13 & 0.07 & 0.03 & 0.04 & 0.28 & 0.11 & 0.06 \\
\hline Rate of participation of men & 27 & 0.68 & 0.85 & 0.77 & 0.05 & 0.70 & 0.84 & 0.77 & 0.04 \\
\hline Unemployment rate of men & 27 & 0.02 & 0.10 & 0.06 & 0.02 & 0.04 & 0.25 & 0.11 & 0.05 \\
\hline $\begin{array}{l}\text { Rate of participation of } \\
\text { 16-64 year-olds }\end{array}$ & 27 & 0.59 & 0.81 & 0.71 & 0.06 & 0.63 & 0.80 & 0.71 & 0.05 \\
\hline $\begin{array}{l}\text { Unemployment rate of } \\
\text { 15-64 year-olds }\end{array}$ & 27 & 0.03 & 0.11 & 0.06 & 0.02 & 0.04 & 0.25 & 0.11 & 0.05 \\
\hline $\begin{array}{l}\text { Unemployment rate of } \\
\text { 20-24 year-olds }\end{array}$ & 27 & 0.04 & 0.21 & 0.13 & 0.05 & 0.07 & 0.54 & 0.23 & 0.11 \\
\hline $\begin{array}{l}\text { Rate of participation of } \\
\text { 20-24 year-olds }\end{array}$ & 27 & 0.45 & 0.82 & 0.64 & 0.11 & 0.45 & 0.78 & 0.60 & 0.11 \\
\hline Part-time jobs & 27 & 0.02 & 0.47 & 0.14 & 0.10 & 0.02 & 0.49 & 0.15 & 0.10 \\
\hline $\begin{array}{l}\text { Older employers/total } \\
\text { population employed }\end{array}$ & 27 & 0.00 & 0.07 & 0.02 & 0.02 & 0.01 & 0.07 & 0.02 & 0.01 \\
\hline Long term unemployment & 27 & 0.00 & 0.02 & 0.01 & 0.00 & 0.00 & 0.04 & 0.02 & 0.01 \\
\hline Valid N (listwise) & 27 & & & & & & & & \\
\hline
\end{tabular}

Source: Own calculations (2013) 


\section{Conclusion}

With the usage of the method of cluster analysis, the authors of this paper have divided the countries of the European Union 27 into 4 groups, which have similar characteristics of labor market. 11 variables have been chosen, such as unemployment and the rate of participation of different groups of employers. The aim of the paper was to discuss the impact of the current economic crisis and the situation before and during the crisis was compared.

The current economic recession has dramatically affected the situation on the labor market. If we look at the European Union 27 as a whole, the rate of unemployment has increased in all of the observed groups of employees. The biggest deterioration was detected in the group of young people, which can be considered as a group of absolvents.

The impact of the crisis is different between countries. The worst situation occurred in Southern Europe (namely, Spain and Greece), where the rate of unemployment has dramatically increased. These two countries were separated from the rest of the countries and created a separate cluster in 2012. The countries from the West of Europe and Nordic countries had the best values of the monitored variables. There countries were Germany, the Netherlands, Denmark, Austria, Finland, Sweden and the UK.

\section{Acknowledgment}

This article was created with the help of the Internal Grant Agency of University of Economics in Prague No. 6/2013 under the title "Evaluation of results of cluster analysis in Economic problems".

\section{References}

1. Aaronson, S.; Fallick, B.; Figura, A.; Pingle, J. et al. The Recent Decline in the Labor Force Participation Rate and Its Implications for Potential Labor Supply/Comments and Discussion. Brookings Papers on Economic Activity. 2006.

2. Azmat, G.; Güell, M.; Manning, A. Gender Gaps in Unemployment Rates in OECD Countries. Journal of Labor Economics. 2006, 24(1): 1-37.

3. Calinski, T.; Harabasz, J. A Dendrite Method for Cluster Analysis. Comunications in Statistics. 1974, 3: 1-27.

4. Chapman, B. Long Term Unemployment: The Case for Policy Reform. The Economic and Labor Relations Review: ELRR. 1993, 4(2): 218-240.

5. Davies, D. L.; Bouldin, D. W. A Cluster Separation Measure. IEEE Transactions on Pattern Analysis and Machine Inteligence. 1979, 4: 224-227.

6. Elder, S. Global Employment Trends for Youth. International Labor Organization, represented by the International Labor Office (ILO). Geneva, 2010.

7. EUROSTAT Database. Labor Market Statistics, Labor Force Survey [interactive]. [accessed on 25-08-2013]. <http://epp.eurostat.ec.europa.eu>. 
8. Gan, G.; Ma, Ch.; Wu, J. Data Clustering Theory, Algorithms, and Applications. ASA-SIAM. Philadelphia, 2007.

9. Halkidi, M.; Batistakis, Y.; Vazirgiannis, M. On Clustering Validation Techniques. Journal of Intelligent Information System. 2001, 2-3: 107-145.

10. Halkidi, M.; Batistakis, Y.; Vazirgiannis, M. Clustering Algorithms and Validity Measures. SSDBM. Athens, 2001.

11. Hotchkiss, J. L. Changes in the Aggregate Labor Force Participation Rate. Economic Review - Federal Reserve Bank of Atlanta. 2009, 94(4): I,1-6.

12. Kieselbach, T. Long-Term Unemployment among Young People: The Risk of Social Exclusion. American Journal of Community Psychology. 2003, 32(1/2): 69-76.

13. Kjeldstad, R.; Nymoen, E. H. Part-time Work and Gender: Worker versus Job Explanations. International Labour Review. 2012, 151(1): 85-107.

14. Masso, J.; Krillo, K. Labor Markets in the Baltic States during the Crisis 2008-2009: The Effect on Different Labor Market Groups. SSRN Working Paper Series. Rochester, 2011.

15. Pavelka, T. Long-term Unemployment in the European Union during the Last Five Turbulent Years. Intellectual Economics. 2012, 6(3): 293-305.

16. Řezanková, H.; Húsek, D.; Snášel, V. Shluková Analýza Dat. Second edition. Prague: Professional Publishing, 2009. Sher, V. Who Is Hit Hardest during a Financial Crisis? The Vulnerability of Young Men and Women to Unemployment in an Economic Downturn. International Labour Organization (ILO) and The Institute for the Study of Labor (IZA). Bonn, 2009.

17. Scarpetta, S.; Sonnet, A.; Manfredi, T. Rising Youth Unemployment during the Crisis: How to Prevent Negative Long-term Consequences on a Generation? OECD Social, Employment and Migration Papers. 2010, 106. Paris.

18. Spěváček, V.; Vintrová, R.; Zamrazilová, E.; Ždárek, V.; Rojíček, M. Makroekonomická analýza-Magisterský kurz. VŠEM. 2010.

19. Wickens, M. Macroecomic Theory, A Dynamic General Equilibrium Approach. Second Edition. Princeton University Press, 2012.

\section{KLASTERINE் ANALIZE் KAIP İRANKIS ES KLASTERIŲ POVEIKIUI DARBO RINKAI VERTINTI IKI IR PO EKONOMINĖS KRIZĖS}

Santrauka. Straipsnio tikslas yra panaudoti klasterinę analizę klasterių struktūros pokyčiams nustatyti ES šalyse krizės laikotarpiu. Klasterinès analizės pagrindiniai duomenys yra darbo rinkos charateristikos ES šalyse. Padètis darbo rinkoje yra laikoma vienu svarbiausiu ir daugiausiai aptariamu šalies ekonomikos veiksniu. Aptariamas ekonominès krizės poveikis darbo rinkos struktūros pokyčiams ES šalyse iki ekonominès krizės (iki 2008 m.) ir ekonominès krizès metu (iki $2012 \mathrm{~m}$.). Klasterinè analizė pritaikyta grupuojant šalis. Naudoti šie darbo rinkos rodikliai: nedarbas skirtingo amžiaus grupėse, nedarbas pagal lyties požymius bei šių grupių dalyvavimo darbo rinkoje lygis.

Tomáš PIVOŇKA - Ing, PhD Student, Faculty of Business Administration of University of Economics in Prague. Research field: Macroeconomic research, current account analysis.

Tomáš PIVOŇKA - Verslo administravimo fakulteto doktorantas, Prahos ekonomikos universitetas. Mokslinių interesų sritis: Makroekonomikos tyrimai, einamụjų sąskaitų analizè. 
Tomáš LÖSTER - Ing, PhD, Assistant Professor, Faculty of Informatics and Statistics of University of Economics in Prague. Research field: Cluster analysis, statistical methods.

Tomáš LÖSTER - Informatikos ir statistikos fakulteto docentas, mokslų daktaras, Prahos ekonomikos universitetas. Mokslinių interesų sritis: klasterinè analizè, statistiniai metodai. 